\title{
Effect of the Constructivist Method on Junior Secondary School Students' Achievement in Poetry: Implications for School Counseling in Nigeria
}

\author{
Felix Okechukwu Ugwuozor ${ }^{1}$, Moses Onyemaechi Ede ${ }^{1}$, Godwin C. Abiogu ${ }^{1}$, Justus Chidi Ugwu ${ }^{2}$ \\ Damian C. Ncheke ${ }^{1}$, Amuche Nnamani ${ }^{3}$, Florence C. Albi-Oparaocha ${ }^{4} \&$ Chinweike Obiweluozor ${ }^{1}$ \\ ${ }^{1}$ Department of Educational Foundations, Faculty of Education, University of Nigeria, Nsukka, Nigeria \\ ${ }^{2}$ Department of English and Literary Studies, Faculty of Art, University of Nigeria, Nsukka, Nigeria \\ ${ }^{3}$ Department of Arts Education, Faculty of Education, University of Nigeria, Nsukka, Nigeria \\ ${ }^{4}$ Department of Educational Foundations, Faculty of Education, Alex Ekwueme Federal University, Ndufu-Alike \\ Ebonyi State, Nigeria \\ Correspondence: Godwin C. Abiogu, Department of Educational Foundations, Faculty of Education, University of \\ Nigeria, Nsukka, Nigeria. E-mail: godwin.abiogu@unn.edu.ng
}

Received: December 11, 2019 Accepted: April 6, 2020 Online Published: April 30, 2020

doi:10.5539/gjhs.v12n5p80

URL: https://doi.org/10.5539/gjhs.v12n5p80

\begin{abstract}
This study examined the effect of the constructivist method on junior secondary school students' achievement in poetry in Nigeria. Sixty junior secondary class-two students participated in the study. The instrument used was a questionnaire developed by the researchers. The experiment consisted of 12 weeks of full intervention and 6 weeks of follow-up meetings. The study used repeated-measures ANOVA to see the achievement level in poetry of each participant across control and treatment groups post intervention. Results show a significant effect for the constructivist method on achievement in poetry among students in the treatment group compared to the control group. They also show that the effect of the constructivist method on students' achievement in poetry is not determined by gender. The implications for research and practice are discussed in accordance with these outcomes. The researchers conclude by emphasizing the importance of a follow-up study in the Nigerian context that would make the teaching method more robust through the use of the constructivist method for high academic achievement and improved school counseling.
\end{abstract}

Keywords: Constructivist method, achievement, poetry, teachers, counseling

\section{Introduction}

Gone arethedays when learning was repetitive, a period where curriculum activities relied heavily on textbooks and literacy. Learners were viewed as blank slates, onto which information was etched by the teacher. Students at that time were not allowed to drive knowledge, interest, experience, ideas, or thought via critical thinking. Rather, they were introduced only to basic knowledge that limited them to performing problem-solving tasks. Learners were regarded as passive participants instead of having education be centered on them. Teachers were using the traditional approach during teaching and learning, one that only required demonstration of mastery of conventionally accepted knowledge (Kim, 2005). Since then, the constructivist method has emerged to challenge the traditional theory of learning (Mvududu \& Thiel-Burgess, 2012).

Constructivism has no universal definition (Mvududu \& Thiel-Burgess, 2012). Unlike learners in the past, those in a constructivist classroom are information constructors who bring previous experience into the limelight and construct new knowledge in a given situation (Khalid \& Azeem, 2012). In Khalid and Azeem's view, constructivism is a paradigm that hypothesizes learning as an active, contextualized, or constructive process. Constructivism is also perceived as a method by which instruction is mapped and organized to enable students to utilize their innately constructed ideas and thoughts to actively innovate knowledge that is meaningful to them (Borich \& Tombari, 1995). It is likewise defined as a psychological movement that posits that humans construct knowledge and meaning from their experiences (Bimbola \& Daniel, 2010). In operational terms, constructivism is method that hypothesizes that ideas, intuition, and cognition are constructed or developed through the interaction 
of innate drive and experience. Active participation is highly emphasized in constructivism. In essence, learning is not attained but created.

Constructivism has gained a rich background from the fields of philosophy, sociology, psychology, and education (Bimbola \& Daniel, 2010). Due to the different backgrounds from which constructivism emerged, it has a good number of variations, and the two most popular include personal constructivism, attributed to Jean Piaget, and social constructivism, propounded by Lev Vygotsky (Mvududu \& Thiel-Burgess, 2012). Others include radical constructivism advocated by von Glasersfeld (1995), constructivist epistemologies, and educational constructivism by Mathews (1998). This study will focus on personal constructivism, because the researchers intend to observe and guide students as they construct, hypothesize, and experiment with reality to draw inference or learning experiences. Using the personal constructivist method offers the student the opportunity to construct ideas, skills, and knowledge based on their past experiences (Uwalaka \& Offorma, 2015).

Personal constructivism views learning on the basis of personal experience or experiential learning. It is a fundamental method of learning that emphasizes how learning or knowledge is based on innate abilities and self-discovery (Mvududu \& Thiel-Burgess, 2012). Personal constructivism therefore uses the students' natural capacities to drive knowledge through experience (Nedha, 2015). It is on this basis that Piaget developed two important principles: organization and adaptation. Organization means all the cognitive structures that are interconnected as well as fitting any incoming experience into the existing structure (Ngwoke \& Eze, 2004). It is the innate tendency of ordering information, ideas, and experience in a systematic manner to make learning more sophisticated. Constructivists contend that the organization of personal activity is fundamentally self-referent or recursive. This makes the body a fulcrum of experiencing and honors a profound phenomenological sense of selfhood or individuality (Bimbola \& Daniel, 2010). Adaptation is defined by Ngwoke and Eze (2004) as the tendency for all species to adapt to their environment. Operationally, adaptation is regarded as psychological adjustment in the learning environment to allow cognitive structure to be stabilized.

Unlike Piaget's line of thought, social constructivism is concerned with life experience, or the world as it is felt and understood by social actors (Schwandt, 1994). Contextually, social constructivism is the ability to construct experience from social agents and interaction. Mvududu and Thiel-Burgess (2012) noted that social constructivism viewed cognitive development primarily as a function of cultural, historical, and social interaction rather than of individual construction. In line with the social construct of knowledge, Au (2005) pointed out that social constructivism is seen as encompassing a wide range of phenomena, from historical, political, and cultural trends to face-to-face interactions, reflecting group processes both explicit and implicit with intended and unintended consequences. Social constructivism therefore involves the perception of a learner within a social environment. $\mathrm{Au}$ (2005) observed that the emphasis is on the process of knowledge construction by the social group and the intersubjectivity established through the interactions of the group.

In fact, whether knowledge or learning is perceived to be socially constructed or personally constructed, the important thing is that the constructivist method has implications for learning conceptualization. Moreover, learners construct new understandings using what they already know (Mvududu \& Thiel-Burgess, 2012). It is either that the previous experience is individually or socially constructed. The underlying point according to Mvududu and Thiel-Burgess is that learners' prior knowledge influences what new or modified knowledge they will construct from the new experiences. This shows that constructivism has important implications for teaching. Consequent upon this, the role of the constructivist method cannot be glossed over. Therefore, a constructivist teacher does not take the role of "the sage on the stage" but rather "a guide on the side," who provides students with opportunities to test the adequacy of their current understanding. Khalid and Azeem (2012) opined that constructivist teachers ensure that students are allowed to make use of preexisting conceptions and construct knowledge rather than reproduce a series of facts. From the foregoing, a constructivist teacher guides learners to formulate, reformulate, and create information through previous experiences.

Other scholars have also expressed the effectiveness of constructivist teaching. For instance, Altun and Buyukduman (2007) wrote that by using the constructivist method in education, students appear to be more on task and active during the class hour and stated that they were better able to connect their learning to previous knowledge by participating more in group work. Rationale of using constructivist method was based on the primary assumption that a student has the ability to construct idea and knowledge to solve problems one could encounter in the environment. Therefore, the teachers' role is to provide suitable and conducive atmosphere for learning. In view of that, we assumed that adapting constructivist method for helping students' active role in development and learning could be achieved.Altun and Buyukduman further expressed that this increased participation in the classroom resulted in more permanent retention of the vocabulary. Similarly, Khalid and 
Azeem (2012) asserted that the constructivist method of teaching helps students perform better and achieve high scores in literary studies. Zehr (2006) asserted that a collaborative approach to teaching in a literature classroom was highly effective in increasing students' literary appreciation and helping them become more comfortable working in an inclusive classroom.

Furthermore, Cummins et al. (2005) hold the view that these two main concepts are essential to academic success. For studies in poetry, students are to incorporate some aspects of their native languages and academic ability from their previous experiences into their studies in poetry and should be affirmed in their cultural identity. This shows the relationship between constructivism and poetry.

As with constructivism, there is no single definition of poetry. Scholars' definition of poetry could be likened to the nine blind men whose varying accounts of the proverbial elephant only portrayed the parts of the animal each has touched. Wordsworth (1798) defined poetry as an expression of strong feelings, usually rhythmical, that takes its origin from the spontaneous overflow of deep emotion, recollected in tranquility. Wordsworth was of the view that it was strong emotion or feeling that evokes poetic thought in people. By implication, poetic occurrence is instinctive and sudden (spontaneous overflow) but calmly arranged because it has a definite pattern to follow (recollected in tranquility). Wordsworth's definition shows that the "sage on the stage" method cannot work in the teaching of poetry since poetry is instinctive. The teacher can, at best, serve as a "guide on the side," at which point he or she may guide the students on structural arrangement (lines and stanzas) and how to manipulate sound devices to achieve rhythm.

Mojo (1971) stated that poetry is the music invoked in men's hearts according to the age in which they live. He said that poetry is a synopsis of the music (events) that characterizes the age (society) of the poet. Mojo's view of poetry aligns with Wordsworthian orientation that poetry is instinctive. In a similar spirit, Okoro (2014) viewed poetry as the search for the missing electrons in the atom of the soul. The knowledge gap that exists in society makes poetry inevitable (Okoro, 2014). For him, the poet is the voice of the voiceless, and it is societal pain that causes the poet personal pain. Emphasizing on the structural-cum-semantic interweave of good poems, Okoro (2012) asserted that poetry is located at the junction where sound and meaning meet.

In line with the preceding scholarly definitions of poetry, teaching of poetry therefore favors the learner-centered constructivist method versus the teacher-centered traditional method. A popular opinion among scholars is that there has been a decline in Nigerian students' performance in poetry studies. Both stakeholders in the educational sector and the general public have bemoaned this overwhelming tide of deterioration. This deterioration and its attendant indices of truancy and examination malpractices are irrigated by poor teaching and methods. Okorie (1984) viewed examination malpractice as one of the major problems affecting the performance of students in poetry. Okorie argued that the success of any developing nation, such as Nigeria, will be determined largely by its ability to shape its destiny in the light of unleashed human intelligence. Okorie also identified poor teacher quality as one of the major factors harming students' performance in poetry.

Oribabor (2014) argued that psychosocial phobia in the form of an inferiority complex, coupled with the chances of not being oneself, often affects children of low economic status in their performance in poetry. Oribabor claimed that most students find poetry difficult because their psychomotor domain may not be sophisticated enough for them to study poetry, which they think is hard to study. We agree with the views of Oribabor and the preceding scholars that students' performance in poetry is on the decline. We believe this is mostly caused by the erroneous habit of teachers imposing their ideas of poetry on students instead of nurturing students' innate poetic qualities, since poetry is largely inherent. Ugwuja (2007) found that many community secondary schools in Nigeria lack qualified teachers in most subject areas, including English literature. Ugwuja also noted that it is most often worse in literature-related subjects. Teachers lack appropriate methods to teach their students creative or constructive skills involved in poetry (Ene, 2007). We believe poetry teachers have not been exposed to other teaching methods like constructivism; therefore, they are still using the traditional method. Consequently, the worsening performance among students in poetry appears to be linked to the conventional method.

From the general observations of the researchers as teachers, junior secondary school students in the Isi-Uzo Local Government Area of Enugu State seem to have been performing low in English Literature, especially in the poetry section. Su and Wang (2010) decried the number of students that have not achieved the desired performance goals in creative skills.

Achievement, according to Hong and Lee (2003), is to complete, accomplish, or get something done. Oodo (2015) opined that achievement is defined as accomplishing whatever goals have been set to be accomplished. Contextually, achievement is the success or failure accomplished at the end of any task through one's knowledge construction and thoughtful reflection on experience. Achievement in poetry in this context is measured by 
students' creative and instinctual ability to convince the reader with a well-articulated write-up in line with rhythmic flow of thought, regardless of the students' gender.

Gender is another factor in this research work. The term gender, according to Nnachi (2007) refers to social roles, traditional expectations, cultural assumptions, and beliefs about the nature and character of biological differences among the sexes. Some research reports suggest that female students show a small but significant superiority over the male students in linguistic attitude (Nnachi, 2007). However, Ellis (1994) posited that it will not always be the case that women outperform in poetry classes. Studies have delineated that male and female students who are exposed to the constructivist method perform equally. For instance, Akinbobola andAfolabi (2009) found that there is no significant difference in the achievement of male and female physics students taught with a guided-discovery teaching approach. Peter, Abiodun, and Jonathan (2010) also revealed that significant differences do not exist between male and female students exposed to the constructivist approach. Duyilemi and Bolajoko (2014) indicated thatmale students had higher achievement scores than their female counterparts in the experimental group.

Against this background, this study investigated the effect of constructivist method on junior secondary school students' achievement in poetry in the Isi-Uzo Local Government Area of Enugu State. Literature is a very important subject in Nigerian educational and social spheres; yet despite this status, junior school students' performance level in it is still discouragingly poor. In addition, junior secondary school students in the Isi-Uzo area seem to have been performing particularly low in poetry. Experience has shown that Nigerian students' achievement in poetry has declined, to the distress of educational stakeholders and the public.

In Nigeria, poetry has never been neglected in the teaching of Literature in English (Abatan, 2014; Myschool, 2018). Some secondary school teachers use the conventional method, which appears to be described as inappropriate for teaching poetry. The researchers felt that using a different approach, the constructivist method, which is student centered, could change the achievement level and interest of students in poetry. Therefore, the problem of this study is what alternative method will have a more positive effect on students' achievement in poetry in the Isi-Uzo Local Government Area. This study posed to ask what is the effect of the constructivist method on junior school students' achievement in poetry in Isi-Uzo? The study hypothesized that (1) the constructivist method will have a significant effect on students' achievement when taught poetry in the treatment group compared to the control group, and (2) the effect of the constructivist method on students' achievement in poetry will not be determined by gender.

\section{Method}

\subsection{Ethical Approval}

The ethical approval for conducting this study was granted by the University of Nigeria Nsukka Faculty of Education Research Ethics Committee.

\subsection{Participants}

The participants were from Isi-Uzo Metropolis in Enugu State, Nigeria. The area was chosen because the academic performance of students in their Basic Education Certificate Examination (BECE) on Literature in English appears to be declining, especially in the Isi-Uzo Local Government Area. Isi-Uzo has a population of 12,345 junior secondary school class-two (JSS II) students, consisting of 6,340 boys and 6,005 girls (Post Primary School Management Board, Enugu State, 2015/2016). From this population, the researchers sampled the 60 JSS II students from two secondary schools. A sample size of 60 students was considered appropriate because the students responded to treatment willingly. A deliberate sampling technique was used to achieve that effect. In addition, sample -criterion of inclusion was based on low poetry scores of below $40 \%$. A simple random sampling technique for intact classes enabled the researchers to select two secondary schools, which were randomly assigned to experimental and control groups. In each school, two intact classes with 30 JSS II students each (experimental and control groups) were randomly selected for the study.

\subsection{Procedure}

The researchers used multistage sampling involving stratified, simple random (use of envelopes), and purposive sampling techniques to successively choose the area of Eha-Amufu, schools, locations, gender, classes, and, last, the participants used for the study. The purposive sampling exercise produced a total of 60 participants from those students $(N=12,345)$ in JSS II as they fully met the inclusion criteria. Participants were recruited over the course of 6 weeks through schools and class visits. The inclusion criteria, apart from offering Literature in English, are that the participant must have recorded low achievement (low poetry scores of below $40 \%$ ) in the poetry aspects of the subject, be readily available for the study, and also give informed consent. 
The experimental group was taught using a constructivist approach while the control groups were taught same topic using the conventional method. The instrument for data collection (Poetry Achievement Test; PAT) was administered to students in the two groups (experimental and control groups) before the commencement of the treatment. Both groups received 4 weeks of full intervention and 2 weeks of follow-up meetings that marked the end of intervention. A few weeks before the actual teaching commenced, the regular Literature in English two teachers per school site were employed and briefed. The briefing exercise was based on the purpose of the study, the topics to be taught, the use of the lesson plan prepared by the researchers, and the teaching methods of the study. Two teachers were instructed to teach both the experimental and control groups using the lesson plan for each group. The teachers in the experimental group were advised to use the constructivist approach; those in the control group were asked to use the conventional approach. The teachers taught the control and the experimental groups under researchers' supervision.

Post intervention (Time 2) scores were recorded and used to provide information on students' achievement. Follow-up sessions (Time 3), which occurred at Third Term of the school calendar year, were also provided to individual participants in the treatment group. This gave the opportunity of sharing with group members and the researchers how they were able to put into effective use the constructivist method they learned in their initial participation.

\subsection{Measures}

PAT: This is a 15-item essay-type questionnaire on poetry, an aspect of Literature in English in the Nigerian Junior Secondary Schools' syllabus. The questionnaire items were developed based on the Nigerian JSS II unit plan in poetry. Content validity of the instrument was established by two independent experts with Ph.D in Literature in English and further confirmed by a third expert in the subject area with specialization in poetic devices. Inter-scorer reliability of the PAT was .81 (Pearson's $r$ ). A test blueprint was used to derive the list of items of the PAT (see Table 1).

Table 1. Test Blueprint on Poetry Achievement Test

\begin{tabular}{llllll}
\hline \multirow{2}{*}{$\mathbf{S} / \mathbf{N}$} & Content Dimension & \multicolumn{5}{l}{ Ability Process Dimension } \\
\cline { 3 - 6 } & \multicolumn{4}{l}{ Lower Cognition High Cognition Total } \\
\cline { 3 - 6 } & $\mathbf{\%}$ & $\mathbf{6 0}$ & $\mathbf{4 0}$ & $\mathbf{1 0 0}$ \\
\hline $\mathbf{1}$ & Definitions of poetry & 10 & 1 & 1 & 1 \\
$\mathbf{2}$ & Importance of poetry & 10 & 1 & 1 & 2 \\
$\mathbf{3}$ & Structure of a poem & 20 & 2 & 2 & 6 \\
$\mathbf{4}$ & Figurative patterns & 25 & 4 & 3 & 8 \\
$\mathbf{5}$ & Literary terms & 35 & 5 & 7 & 20 \\
\hline
\end{tabular}

Note. $\mathrm{S} / \mathrm{N}=$ Serial Number.

\subsection{Intervention: Design of the Constructivist Teaching Method}

The study used a repeated-measures (within-subject) design, which allowed the researchers to measure at Time 1 (preintervention) and Time 2 (postintervention) the participant's level of achievement in poetry. Specifically, the researchers applied repeated-measures ANOVA to see the improvement or change in individual participant and across control and treatment groups' achievement level in poetry postintervention. Furthermore, Lakens (2013) suggested reporting partial eta squared $\left(\eta_{p}^{2}\right)$ for this design. To test gender differences with respect to the effect of the constructivist method on students' achievement in poetry, the researchers adopted a univariate ANOVA. Prior to analyses, screening for missing values and violation of assumptions were done with the aid of SPSS 16; there were no missing values. The researchers also conducted a power analysis to estimate how much larger and appropriate the sample should be for the present study (see Bland, 2008; Button, Ioannidis, Mokrysz, Nosek, Flint, Robinson, \&Munafò 2013; Hoffman, 2010; Siddharth, 2009). 


\section{Results}

Table 2. Summary Statistics for Repeated-Measures ANOVA of Outcome Variables by Treatment Condition and Time as measured by PAT

\begin{tabular}{|c|c|c|c|c|c|c|c|c|c|c|c|}
\hline & \multicolumn{3}{|c|}{ Control Group } & \multicolumn{3}{|c|}{ Treatment Group } & \multirow{3}{*}{$d f$} & \multirow{3}{*}{$F$} & \multirow{3}{*}{ Sig. } & \multirow{3}{*}{$\eta_{p}^{2}$} & \multirow{3}{*}{$\begin{array}{l}\text { Obs. } \\
\text { Power }\end{array}$} \\
\hline & Time 1 & Time 2 & Time 3 & $\begin{array}{l}\text { Time } \\
1\end{array}$ & Time 2 & Time 3 & & & & & \\
\hline & $M(S D)$ & $M(S D)$ & $M(S D)$ & $\begin{array}{l}M \\
(S D)\end{array}$ & $M(S D)$ & $M(S D)$ & & & & & \\
\hline \multirow[t]{3}{*}{ PAT } & $\begin{array}{l}28.13 \\
(0.43)\end{array}$ & - & - & $\begin{array}{l}28.27 \\
(0.98)\end{array}$ & - & - & $(1,58)$ & 0.68 & .498 & .008 & - \\
\hline & - & $\begin{array}{l}27.60 \\
(1.13)\end{array}$ & - & - & $\begin{array}{l}85.13 \\
(0.35)\end{array}$ & & $(1,58)$ & 266.11 & .000 & .999 & 1.000 \\
\hline & - & - & $\begin{array}{l}27.03 \\
(1.81)\end{array}$ & & - & $\begin{array}{l}86.33 \\
(1.52)\end{array}$ & $(1,58)$ & 137.58 & .000 & .997 & 1.000 \\
\hline
\end{tabular}

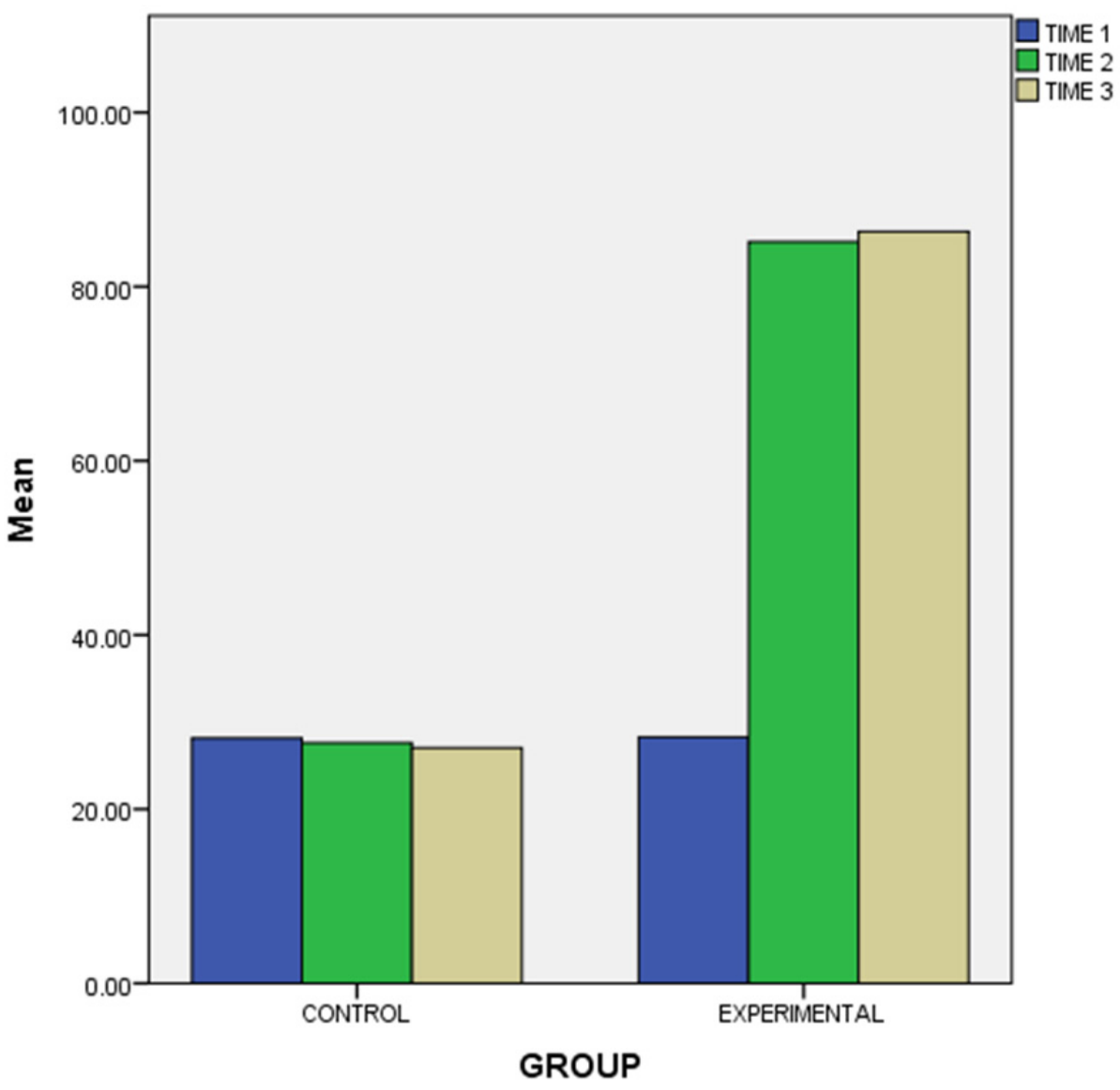

Figure 1. Effect of the Constructivist Method on Students' Achievement in Poetry by Time and Group

To test the hypothesis that there will be a significant effect of the constructivist method on students' achievement when taught poetry in the treatment group compared to the control group, a repeated-measures ANOVA was conducted. The analysis (Table 2) revealed that at Time 1, PAT scores obtained from participants in the control and treatment groups were $28.13 \pm 0.43$ and $28.27 \pm 0.98$, respectively. At Time 1 , low scores and no significant difference were observed in the mean achievement on poetry among the participants in both groups, $F(1,58)=$ 
$0.68, p=.49, \eta_{p}^{2}=0.008$.

At Time 2, PAT scores obtained were $27.60 \pm 1.13$ and $85.13 \pm 0.35$ in the control and treatment groups, respectively, which showed that the level of students' achievement significantly changed, $F(1,58)=266.11, p$ $=.000, \eta_{p}^{2}=0.99$. An $\eta_{p}^{2}$ value of 0.99 indicates that there was a significant effect of the constructivist method on achievement in poetry among students in the treatment group versus those in control group (see Table 2). At Time 3 (6-month follow-up), the effect of the constructivist method on achievement in poetry remained consistent among the students in the treatment group versus those in control group, $F(1,58)=137.58, p=.000, \eta_{p}^{2}=0.99$.

Table 3. Summary Statistics for Repeated-Measures ANOVA of Outcome Variables for Treatment Group by Gender as measured by PAT

\begin{tabular}{|c|c|c|c|c|c|c|c|c|c|c|c|}
\hline \multicolumn{3}{|c|}{ Male } & \multicolumn{4}{|c|}{ Female } & \multirow{3}{*}{$D f$} & \multirow{3}{*}{$F$} & \multirow{3}{*}{ Sig. } & \multirow{3}{*}{$\eta_{p}^{2}$} & \multirow{3}{*}{$\begin{array}{l}\text { Obs. } \\
\text { Pow. }\end{array}$} \\
\hline Time 1 & Time 2 & Time 3 & Time 1 & Time 2 & Time 3 & & & & & & \\
\hline$M(S D)$ & $M(S D)$ & $M(S D)$ & $M(S D)$ & $M(S D)$ & $M(S D)$ & & & & & & \\
\hline $28.44(1.09)$ & - & - & $28.07(0.8$ & 83) & & - & $(1,58)$ & 1.02 & .316 & 0.036 & 0.167 \\
\hline - & $\begin{array}{c}85.13 \\
(0.34)\end{array}$ & - & - & $\begin{array}{l}85 . \\
(0.3\end{array}$ & & - & $(1,58)$ & 0.14 & .891 & 0.001 & 0.052 \\
\hline - & - & $86.44(0.81)$ & - & 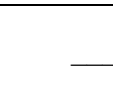 & & $\begin{array}{l}86.21 \\
(2.08)\end{array}$ & $(1,58)$ & 0.40 & .695 & 0.006 & 0.067 \\
\hline
\end{tabular}

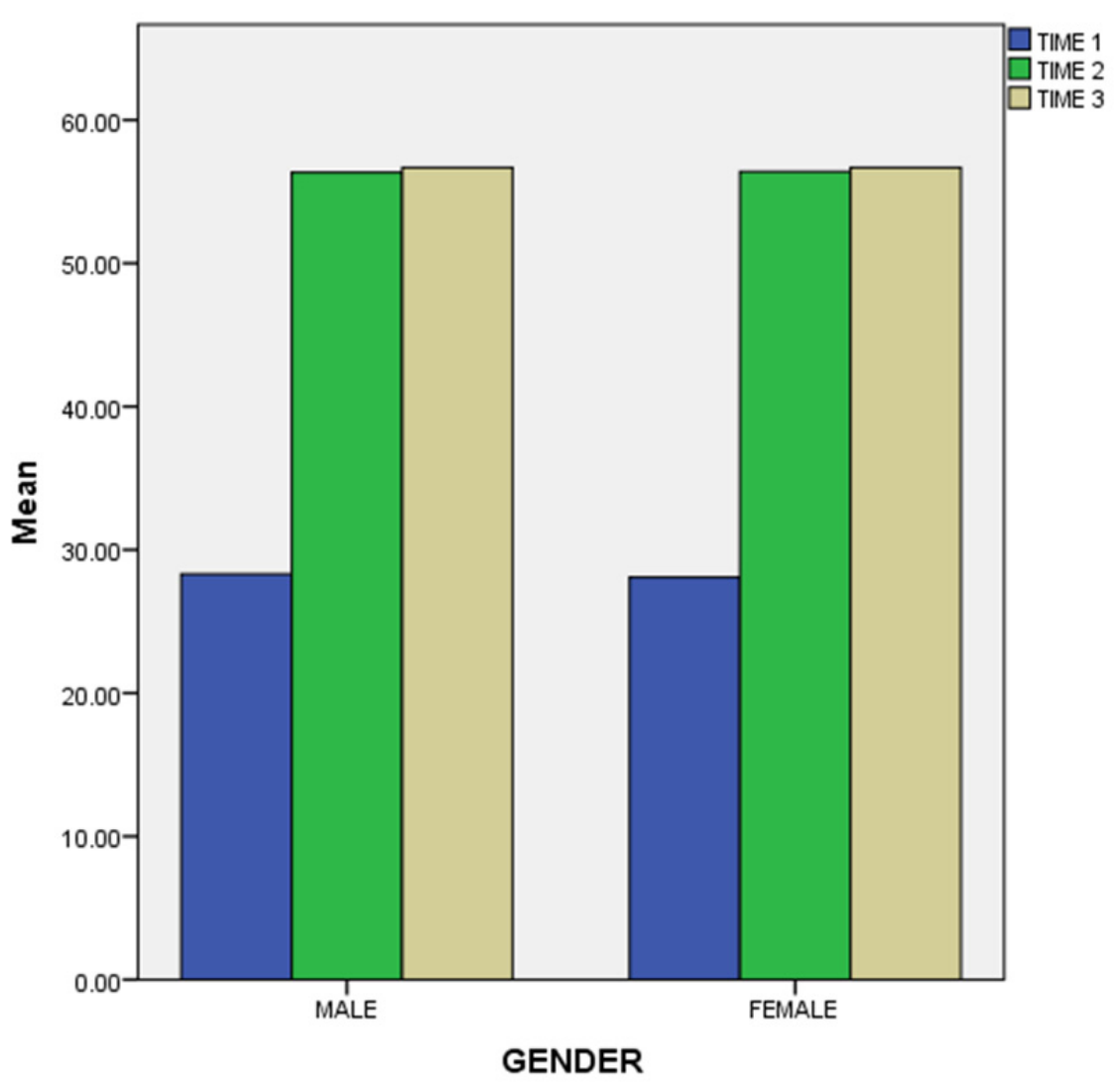

Figure 2. Effect of the Constructivist Method on Students' Achievement in Poetry by Time and Gender

To test the hypothesis that the effect of the constructivist method on students' achievement in poetry will not be determined by gender, a repeated-measure ANOVA was conducted. Table 3 shows that at Time 1, PAT scores obtained from both male and female participants in the treatment group were $28.44 \pm 1.09$ and $28.07 \pm 0.83$, 
respectively. At Time 1, low scores and no significant difference were observed in the mean achievement on poetry among those in the treatment group, $F(1,28)=1.02, p=.32, \eta_{p}^{2}=0.17$.

At Time 2, PAT scores obtained were $85.13 \pm 0.34$ and $85.14 \pm 0.36$ among male and female participants in the treatment group, respectively, which showed that the effect of the constructivist method on level of students' achievement is not determined by gender, $F(1,28)=0.14, p=.89, \eta_{p}^{2}=0.05$. At Time 2 , a value of $\eta_{p}^{2}=0.001$ is an indication that the effect of the constructivist method on students' achievement in poetry is not determined by gender (see Table 3). At Time 3 (6-month follow-up), the effect of the constructivist method on achievement in poetry remained consistent among the students in the treatment group despite their gender, $F(1,28)=0.40, p=.69$, $\eta_{p}^{2}=0.006$

\section{Discussion}

The main purpose of the study was to examine the effect of the constructivist method on junior school students' achievement and interest in poetry. First, the study tested the hypothesis that the constructivist method would have a significant effect on students' achievement when taught poetry in the treatment group versus the control group. The results indicated that there was a significant effect of the constructivist method on achievement in poetry among students in the treatment group versus the control group (see Table 1). This finding disagreed with Bimbola and Daniel (2010), who reported that the constructivist method did not improve students' academic performance. On the other hand, the result supported Khalid and Azeem (2012), who indicated that the constructivist method of teaching increases students' rate of proficiency, raises their satisfaction, and increases their participation. This finding also supports previous studies like Uwalaka and Offorma (2015), Kim (2005), and Ebanks (2010). The effectiveness of constructivism on students' achievement in poetry could be based on the fact that it gives students opportunities to discover and explore information, probably because the constructivist teaching method allows students to use their innate abilities and thoughts to actively employ the knowledge that is important to them. Since this approach equips learners with fundamental knowledge and makes them better at the problem-solving tasks that can prepare them to face the challenges of contemporary society, school counselors and teachers should consider choosing the constructivist method instead of the conventional one.

Second, the study examined whether student gender would predict the effect of the constructivist method on their achievement in poetry. The results indicated that it would not (see Table 2). This finding agrees with Akinbobola andAfolabi (2009), who found that there is no significant difference between the achievement of male and female physics students taught with a guided-discovery teaching approach. The finding corresponds with Peter, Abiodun, and Jonathan (2010), who also found no significant difference between male and female students exposed to the constructivist method. In contrast with the result, Duyilemi and Bolajoko (2014) indicated thatmale students had higher achievement scores than their female counterparts who are exposed to constructivist method. This is not surprising as both male and female students appear to have discovered the teaching method that will be effective in contributing their own idea to learning. This shows that their minds are not totally tabula rasa, or empty slates. It may be that the conventional method allows gender difference among junior secondary students. By contrast, Kim (2005) argued that constructivist method is not effective in relation to self-concept and learning strategy, but had some effect upon motivation, anxiety toward learning, and self-monitoring. This may be attributable to the time factor (the multiple times when scores were taken). Overall, this present study showed that male and female students are capable of competing and collaborating in poetry.

\subsection{Implications}

School counsellors should encourage teachers to apply and utilize the constructivist method during teaching and learning groom and produce higher achievers. Since, students in these poetry classes who were exposed to constructivist teaching performed better than those who were not. They also imply that if English Language teachers start using this method to teach poetry in Nigerian secondary schools, it will reduce students' repeated failure. Many students using a constructivist method may therefore find poetry easier than they thought, because they can use their intuitive and critical abilities when studying. The practice implication is for educational curriculum planners and educators to understand align the views of constructivist method while teaching poetry in classroom. For professional development, English Language teachers should note the need to provide environment that stimulate learning. This could bring students' current understandings to the front position.

The results also indicate that gender had no effect on students' achievement in poetry when using the constructivist method. This implies that both male and female students can compete in terms of poetry. It is therefore important for poetry teachers and school counsellor to start using a constructivist method that is more gender inclusive. This will give these students the psychological readiness to learn better and achieve higher. 
As there is indication that constructivist method is effective in increasing the academic achievement of students in poetry, school counselling practitioners should promote constructivist method of teaching in schools. There is also need for school counsellors to plan about orientation on this method for teachers. School counsellor should sensitize the students that performance in poetry is not dependent on gender. It implies that school counsellor should advocate teachers and students to put constructivist method into practice.

\section{Conclusion}

This study concluded that the constructivist method had a significant effect on achievement in poetry among students in the treatment group versus those in the control group. It also concluded that the effect of the constructivist method on students' achievement in poetry is not determined by gender. Students' academic performance depends not only on what, how, and where they learn but also on their critical thinking. The importance of giving equal opportunities to students regardless of gender cannot be overemphasized.

\section{Competing Interests Statement}

The authors declare that there are no competing or potential conflicts of interest.

\section{References}

Abatan, O. L. (2014). Impact of dramatization and lecture methods on effective teaching of Yoruba Poetry in secondary schools in Lagos State, Nigeria.Journal of Educational and Social Research, 4(3), 161-164.

Akinbobola, A. O., \& Afolabi, F. (2009). Constructivist practices through guided discovery approach: The effect on students' cognitive achievements in Nigerian senior secondary school physics. Bulgarian Journal of Science and Education Policy, 3(2), 233-252.

Altun, S., \& Buyukduman, F. I. (2007). Teacher and student beliefs on constructivist instructional design: A case study. Educational Sciences: Theory \& Practice, 7(1), 30-39.

$\mathrm{Au}, \mathrm{K}$. H. (2005). Social constructivism and the school literacy learning of students diverse backgrounds. Journal of Literacy, 7(30), 29-79.

Bimbola, O., \& Daniel, O. I. (2010). Effect of constructivist-based teaching strategy on academic performance of students in integrated science at the junior secondary school level. Educational Research and Review, 5(7), 347-353.

Bland, M. (2008).Some problems with sample size. Paper presented at the Joint Meeting of the Dutch Pathological Society and the Pathological Society of Great Britain \& Ireland, Leeds, July 4. Retrieved from https://www-users.york.ac.uk/ mb55/talks/pathsamp.pdf

Borich, G. D., \& Tombari, M. L. (1995). Educational psychology: A contemporary approach. New York, NY: Harper Collins.

Button, K. S., Ioannidis, J. P., Mokrysz, C., Nosek, B. A., Flint, J., Robinson, E. S., \& Munafò, M. R. (2013). Power failure: Why small sample size undermines the reliability of neuroscience. Nature Reviews Neuroscience, 14(5), 365-376. https://doi.org/10.1038/nrn3475

Cummins, J., Bismilla, V., Chow, P., Giampapa, F., Cohen, S., Leoni, L., \& Sastri, P. (2005). Affirming identity in multilingual classrooms. Educational Leadership, 63, 38-43.

Duyilemi, A. N., \& Bolajoko, A. O. (2014). Effects of constructivists' learning strategies on senior secondary school students' achievement and retention in biology. Mediterranean Journal of Social Sciences, 5(27), 627-633.

Ebanks, R. A. (2010). The influence of learner-centered pedagogy on the achievement of students in title I elementary schools (Unpublished doctoral dissertation). North Central University, San Diego, CA.

Ellis, R. (1994). The study of second language acquisition. Oxford: Oxford University Press.

Ene, N. F. (2007). Effect of Cloze instructional methods on the achievement of students in reading comprehension. International Journal of Arts and Technology Education, 6(2), 75-83.

Hoffman, J. (2010). Sample size matters. Emergency Physicians Monthly. Retrieved from http://www.epmonthly.com/archives/features/sample-size-matters/

Hong, E., \& Lee, K. (2003). Parental awareness of their children's homework motivation and preference and its relationship to achievement. International Journal of Adolescence and Youth, 11, 231-249. https://doi.org/10.1080/02673843.2003.9747931 
Khalid, A., \& Azeem, M. (2012). Constructivist vs. traditional: Effective instructional approach in teacher education. International Journal of Humanities and Social Science, 2(5), 170-177.

Kim, J. S. (2005). The effects of a constructivist teaching approach on student academic achievement, self-concept, and learning strategies. Asia Pacific Education Review, 6(1), 7-19.https://doi.org/10.1007/BF03024963

Lakens, D. (2013). Calculating and reporting effect sizes to facilitate cumulative science: A practical primer for t-tests and ANOVAs. Frontiers in Psychology, 4, 863. https://doi.org/10.3389/fpsyg.2013.00863

Mathews, M. (1998). Constructivism in science education. Dordrecht, The Netherlands: Kluwer. https://doi.org/10.1007/978-94-011-5032-3

Mojo, K. (1971). The early years. Cambridge, Massachusetts: Harvard University Press.

Myschool. (2018). The problems of teaching poetry in junior secondary school in Ikpoba- Okha Local Government Area Edo State. Retrieved from https://myschool.ng/materials/view/the-problems-of-teaching-poetry-in-junior-secondary-school-in-ikpobaokha-local-government-area-edo-state-399912565

Mvududu, N. H., \& Thiel-Burgess, J. (2012). Constructivism in practice: The case for English Language learners. International Journal of Education, 4(3), 108-118.https://doi.org/10.5296/ije.v4i3.2223

Nedha. (2015). Difference between constructivism and social constructivism. Retrieved from http://www.differencebetween.com/difference-between-constructivism-and-vs-social- constructivism/

Ngwoke, D. U., \& Eze, U. N. (2004). Developmental psychology and education: Theories, issues and trends. Enugu, Nigeria: Magnet Business Enterprises.

Nnachi, R. O. (2007). Advanced psychology of learning and scientific enquiries. Enugu, Nigeria: John Jacob's Classic Publishers.

Okorie, D. (1984). Causes of students poor performance in Literature in SSCE in Nigeria: A wholistic overview. Journal of Language Linguistics, 5(2), 177-191.

Okoro, F. U. (2012). When the bleeding heart breaks. Enugu, Nigeria: Chenglo.

Okoro, F. U. (2014). Pimples and dimples. Enugu, Nigeria: El-Demark.

Oribabor, E. A. (2014). Linguistics investigation of the language of Nigerian University students. Ibadan, Nigeria: Hope.

Oodo, A. S. (2015). Influence of parents' child relationships on secondary school students' motivation to learn and academic achievement in Otukpo Education Zone, Benue State (Unpublished master's thesis.) University of Nigeria, Nsukka.

Peter, O. I., Abiodun, A. P., \& Jonathan, O. O. (2010). Effect of constructivism instructional approach on teaching practical skills to mechanical related trade students in western Nigeria technical colleges. International NGO Journal, 5(3), 59-64.

Schwandt, T. (1994). Constructivist, interpretivist approaches to human inquiry. Retrieved from https://www.researchgate.net/publication/232477264_Constructivist_Interpretivist_Approaches_to_Human _Inquiry

Siddharth, K. (2009). Statistical significance and sample size. Retrieved from https://explorable.com/statistical-significance-sample-size

$\mathrm{Su}, \mathrm{C}$. Y., \& Wang, T. I. (2010). Construction and analysis of educational assessments using knowledge maps with weight appraisal of concepts. Computers \& Education, 55(3), 1300-1311. https://doi.org/10.1016/j.compedu.2010.05.027

Ugwuja, J. J. O. (2007). Educational measurement and evaluation at secondary level of Education in Nigeria: The way forward. International Journal of Art and Technology Education, 6(2), 59-74.

Uwalaka, A. J., \& Offorma, G. C. (2015). Effect of constructivist teaching method on students' achievement in French listening comprehension on Owerri North L.G.A of Imo State, Nigeria. Journal of Education and Practice, 6(6), 52-56.

Von Glasersfeld, E. (1995). Radical constructivism: A way of knowing and learning. Studies in mathematics education series: 6. Retrieved from http://files.eric.ed.gov/fulltext/ED381352.pdf

Wordsworth, W. (1798). Lyrical ballad. London: T. N. Longman. 
Zehr, H. (2006). Presentation given at Redeemer University College, Ancaster, Ontario, March 7, 2006.

\section{Copyrights}

Copyright for this article is retained by the author(s), with first publication rights granted to the journal.

This is an open-access article distributed under the terms and conditions of the Creative Commons Attribution license (http://creativecommons.org/licenses/by/4.0/). 